\title{
Effect of Glass Fibers on The Mechanical Behavior As Well As Energy Absorption Capacity and Toughness Indices of Concrete Bridge Decks.
}

Ahmad Jan ( $\nabla$ engr.ahmedjan36@gmail.com )

Zhengzhou University https://orcid.org/0000-0003-2780-7077

Zhang Pu

Zhengzhou University

Kashif Ali Khan

Zhengzhou University

Izhar Ahmad

Hohai University

Irshad Khan

Zhengzhou University

\section{Research Article}

Keywords: Glass fiber reinforced concrete (GFRC), Mechanical properties, Toughness indices, Energy absorption

Posted Date: February 22nd, 2021

DOI: https://doi.org/10.21203/rs.3.rs-217402/v1

License: (c) (1) This work is licensed under a Creative Commons Attribution 4.0 International License. Read Full License

Version of Record: A version of this preprint was published at Silicon on March 8th, 2021. See the published version at https://doi.org/10.1007/s12633-021-01026-2. 


\section{Abstract}

In this study, the incorporation of glass fibers in concrete bridge decks has been studied for improving its mechanical properties as well as energy absorption capacity and toughness indices. The mix proportion of 1:3:2 (cement:sand:aggregate) was selected having water-cement ratio of 0.71 . For the manufacturing of glass fiber reinforced concrete (GFRC), the glass fibers (2-inch) were incorporated at a percentage level of $1 \%, 2 \%, 3 \%$ and $4 \%$ by weight of cement in concrete mixes. The findings reveal that the split-tensile and flexural strength of GFRC increases at all the percentage levels, however, the compressive strength of the blended mixes get reduced by increasing the dosage of glass fibers in the concrete. Besides, the energy absorption and toughness indices are also studied for different types of loadings (i.e. compressive, splitting-tensile and flexural loadings) up to a percentage level of $4 \%$. The findings reveal that the splittensile and flexural energy absorption was increased with the increase in the dosage of glass fibers in comparison with the conventional concrete mixes, however, the compressive energy absorption of the blended mixes get reduced by increasing the dosage of glass fibers in the concrete. Whereas, the toughness indices for compressive, spilt-tensile and flexure was increased while increasing the percentage of glass fibers as compared to the conventional concrete. Among the different percentages of glass fibers, its $4 \%$ addition gives better results as compared to $1 \%, 2 \%$ and $3 \%$. Hence, the $4 \%$ of GF can be suggested to be the optimum percentage of the fibers for the selected mix-design in controlling the resistance of concrete in the bridge decks. Although, the energy absorption of GFRC is lesser in comparison with the toughness indices, GFRC are appropriate for enhancing ductility and resistance against loadings in concrete bridge decks.

\section{Introduction}

Concrete is a commonly utilized material for buildings, however, it is facing numerous deficiencies in the industry of engineering. These deficiencies are higher brittle behavior, low ductility, insufficient impact toughness and lower tensile strain and tensile strength [1-5]. Employing the principle of reinforcing bars at micro level, i.e. addition of different non-continuous fragmented fibers in concrete, such intrinsic shortcomings of concrete might be significantly avoided [6]. At commercial level, a lot of different kinds of fibers are available i.e. glass, steel, naturally produced fibers and synthetically produced fibers [1,714]. Amongst them, glass fiber (GF) is predominant micro-reinforcing material that is prevalently employed for the purpose of enhancing the concrete performance. Hence, predicting the characteristics of concrete reinforced with fibers is a crucial parameter for the secure and reliable construction.

Various investigations with regards to the incorporation of GF in concrete mixtures are performed to improve its mechanical behavior. Addition of GF might tie-up the micro cracks that occurs in the concrete mix by redistributing the stresses and preventing it from diffusing to the edges of the cracks [6,15-17]. Consequently, an enhanced prohibitory influence occurs at the initial and propagating phase of the crack in the matrix that may enhance the related bearing capacity after the ultimate loading [18]. Along with these, achieving a mode of failure in which cracks occurs without breaking [19-21], as a result improve the mechanical behavior of concrete such as, flexure-and tensile strength, ductility, toughness, energy 
absorption and modulus of rupture $[16,17,19,20,22-37]$ that results in changing the behaviour to a ductile material $[29,31,32]$. Most of the mentioned investigations are related to the impacts of fibers on the mechanical and durability characteristics of concrete where a constant water-to-binder proportion was used obtaining an optimum amount of fibers [24,31,32,38-40], without taking into account its influence that is a significant factor while preparing composite cementitious materials. Furthermore, the fibers dispersed in the random pattern might efficiently prevent the crack from widening and propagating in the concrete matrix that improve the post-cracking ductile behavior of concrete when subjected to static as well as impact loadings. The efficiency of fibers in improving the post-cracking behavior is dependent upon the performance of bond that is influenced by various parameters i.e. the amount of fibers in a unit area, shape of fibers, orientation of fibers, aspect ratio and strength of the matrix etc. By the developmental progress in the field of civil engineering, consideration has also been given to the concrete's durability. The incorporation of GF in the concrete may influence its durability. GF might efficiently regulate the cracking potential of plastic shrinkage [41,42], strain at drying shrinkage $[14,21,25,27]$ and improve resistance of freezing and thawing $[14,43-45]$.

The static and dynamic properties of concrete can be enhanced by the utilization of small distinct and homogeneously distributed natural fibers, which act as a crack arrestor [46]. In the early 1940s, glass fiber reinforced concrete (GFRC) was first recognized by the Russians and then the development was followed by the USA, England, and Canada [47]. The GFRC is a combination of cement, sand, aggregate, and glass fibers [48]. The improvement in the durability of concrete is reported by using glass fibers in concrete [4955]. A parametric investigation was carried out by Shirish on GFRC to improve its durability and plummet cracking [46]. Before the application of load, the micro-cracks were developed. These micro-cracks opened up and propagated with the application of load which ultimately resulting in macro cracks. The different mix design ratios were used for the casting of cylinders and beams to assess the compressive and flexural strength. The 1:3.24:5.1 mixed design ratio was used for the control sample with $\mathrm{w} / \mathrm{c}$ ratio of 0.50 . The $0.025 \%$ of glass fiber was added by the total volume of concrete. The compressive and flexural strength was increased by $10 \%$ and $8 \%$ respectively as compared to that of control samples [56]. Globally the glass fiber is mostly produced by the USA, Europe, Latin America, and the Middle East and Africa. [57].

Furthermore, the expansion of corroded steel is responsible to develop cracks and spall in the concrete bridge decks that result in significant cost of rehabilitation and interruption of the traffic [58]. Issues regarding the expansion of corrosion might be solved to protect steel reinforcement from agents that causes corrosion or to use non-corrosive materials for the production of steel. Fiber reinforced polymer (FRP) reinforcement for composite is an alternate choice which is being effectively utilized in various construction applications and are presently employed as a reinforcement in concrete for bridge decks and various other building components [59-62]. In practical terms, various concrete bridge decks are constructed in recent times in North America using GFRP composite reinforcement [63-64]. While facing shortage of funds, the government or the owners of bridge are nowadays seeking for finding alternate materials to be utilized for bridge rehabilitation, replacement and repair. After successfully completion of various FRP bridge deck schemes [65], for example, the Bentley Creek scheme in New York [66], polymer composites nowadays are getting popularity in the applications of civil engineering. Particularly, polymer 
composite demonstrate several benefits over conventional reinforced concrete steel decks that includes resistance to corrosion, easiness in erection, continuous construction and higher ratio of strength to weight. Such features enable composites an option that is extremely desirable.

Concrete bridge decks constructed using GFRP are principally prominent because such types of bridges have satisfactorily replaced traditional concrete steel decks in numerous bridges. In comparison with the steel and concrete decks, GFRP composite decks have considerable benefits because such bridge decks have higher ductility as well as free of corrosion. Besides, GFRP bridge decks probably have lower cost for repairing and have extended service life as compared to traditional concrete decks. GFRP concrete decks possess light weight due to which the self-weight is almost reduced to $80 \%$ in comparison with the traditional concrete decks. And owing to the light weight of the GFRP composite decks, considerably smarter structure of the bridges can be constructed. Moreover, the capacity of the bridge decks when subjected live loadings might be enhanced without enhancing the capacity of the sub-structure when GFRP composite deck is utilized for the purpose of re-decking. As GFRP composite decks are constructed comfortably and rapidly, the constructing period decreases remarkably and the same time the volume of interruption to traffic decreases. By means of this the savings of urban society will be remarkably enhanced with regards to direct or indirect cost.

The necessities of usage of GF in construction applications are increasing day by day. According to the authors, the findings related to different percentages of GF in the development of GFRC are limited. GF is significantly advantageous for improving the flexure and tensile strength of concrete [67-69]. Concrete reinforced with GF has been utilized in several construction purposes practically and acquired the compressive strength up to 40-60 MPa [70]. Concrete reinforced with GF have been widely used for the construction of sewer lines, formworks, roof finishing and head-walls of the mass structures [71]. Considering all of the above mentioned benefits of GF, efforts have been made in this study to conclude findings related to the utilization of different percentages of GF for concrete bridge decks.

\section{Significance Of The Study}

A significant amount of studies has been carried out on the utilization of different fibers for the modification of concrete in order to enhance the mechanical and durability performance of concrete $[37,72]$. Past research studies revealed that GFRC shows better resistant against the aggressive environment and also improve compressive strength of the concrete at 1.5\% dosage [37] and $1.2 \%$ dosage [73] of GF. But on the other hand, some research studies revealed that at $0.5 \%, 1 \%$ and $2 \%$ dosage [56] and $5 \%$ dosage [57] of GF, the compressive strength of the concrete decreases. Therefore, it is very essential to study the trend and effect at different percentage levels of glass fiber (i.e. $1 \%, 2 \%, 3 \%$ and $4 \%$ ) on the mechanical and durability properties of concrete. In this study an attempt was made to develop blended mixes of GFRC and to evaluate the effect of different percentages of glass fiber on mechanical properties and their corresponding toughness indices, pre-cracked energy absorption and total energy absorption in order to obtain optimum value of glass fiber dosage. 


\section{Materials And Methods}

\subsection{Materials}

In this research, the locally available ordinary Portland cement, Fine aggregate of lawrencepur (local name) quarry, the coarse aggregate of Margala (local name) quarry, tap water, and glass fibers having 2" length and diameter of 0.0063 " were used for the production of control samples (CS), as well as for the glass fiber reinforced concrete (GFRC) to assess the effect of GF on the mechanical properties of concrete and their corresponding toughness indices, pre-cracked energy absorption and total energy absorption. The properties of glass fibers used in this study are shown in Table 1 while glass fiber used in this study is shown in the Figure 1 . The maximum size of coarse aggregate was 0.79 " in this study.

Table 1: Mechanical and thermal properties of glass fiber

\begin{tabular}{|lllll|}
\hline Density $\left(\mathrm{lbs} / \mathrm{ft}^{3}\right)$ & $\begin{array}{l}\text { Tensile strength } \\
(\mathrm{MPA})\end{array}$ & $\begin{array}{l}\text { Tensile modulus } \\
(\mathrm{GPA})\end{array}$ & $\begin{array}{l}\text { Linear coefficient } \\
\text { of thermal }(10- \\
6 / \mathrm{K})\end{array}$ & $\begin{array}{l}\text { Elongation at } \\
\text { break \% }\end{array}$ \\
\hline $1.62937 \times 10^{-4}$ & 1595.6 & 72.66 & 5.56 & 3.78 \\
\hline
\end{tabular}

\subsection{Mix proportioning and preparation of specimens}

In this study, the mix design of concrete was prepared for the target strength of $2500 \mathrm{psi}$ in accordance with $\mathrm{ACl} 211$. A total of 135 specimens were casted, 27 for each batch which means 45 specimens for compressive, 45 specimens for Flexural, and 45 specimens for split tensile strength. In order to obtain the average result of each strength, 3 specimens were tested at each curing age. The different batch quantities of the control specimen and GFRC at $1 \%, 2 \%, 3 \%$, and $4 \%$ mixes were calculated accordingly, which is shown in Table 2. For the preparation of different specimens for the compressive, flexural and splitting tensile strength, the molds were oiled and concrete with different percentages of GF were mixed according to the mix design given in Table 2 . Then concrete was poured in the molds and stored for $24 \pm 8$ hours at room temperature. Before the immersion of the specimen in water, specimens were stored in an open environment for 30 minutes and then the specimens were kept in a water tank at $25^{\circ} \mathrm{C}$ and consequently tested at the age of 7,14 , and 28 days. The coefficient of variation (COV) has also been found out for all the test results of 28 days strength as it is an important indicator of the dispersion of dataset.

Table 2: Mix design for mechanical properties evaluation 


\begin{tabular}{|llllll|}
\hline Materials & \multicolumn{5}{l}{ Batch Weights $\left(\mathrm{Ibs}^{\prime} / \mathrm{ft}^{3}\right)$} \\
& $\mathrm{CS}$ & $\mathrm{MS}_{1}$ & $\mathrm{MS}_{2}$ & $\mathrm{MS}_{3}$ & $\mathrm{MS}_{4}$ \\
\hline Cement & 165.3 & 165.3 & 165.3 & 165.3 & 165.3 \\
\hline Coarse aggregate & 330.6 & 330.6 & 330.6 & 330.6 & 330.6 \\
\hline Fine aggregate & 495.9 & 495.9 & 495.9 & 495.9 & 495.9 \\
\hline Water & 115.7 & 115.7 & 115.7 & 115.7 & 115.7 \\
\hline Glass fibers & 0 & 1.7 & 3.3 & 5 & 6.6 \\
\hline
\end{tabular}

\section{Experimental Program}

\subsection{Fresh properties}

For the assessment of the workability of both modified concrete and control sample, slump cone tests were carried out according to the provision of ASTM C143M-15a [74] and the influence of glass fiber (GF) on the workability of concrete with a different fraction of glass fiber are determined. The density of control sample and modified sample were measured according to ASTM C138/C138M-16 [75]. From the workability, it can be predicted that with how much ease a concrete can be placed. The value of slump more than 5 " indicates more workable concrete and less than 1 " tells about the stiffness of concrete. Because of the retention and confinement effect of glass fiber, the workability of GFRC gets reduced by increasing the percentage of glass fiber. A similar trend of workability was reported by previous researches $[2,56]$. The corresponding results are listed in Table 3.

Table 3: W/C ratio, Mix design ratio, Slump and density of CS and GFRC

\begin{tabular}{|llllll|}
\hline Samples & W/C ratio & Mix design ratio & Slump(in.) & Density (lbs. /cft.) & Drop in Density (\%) \\
\hline CS & 0.71 & $1: 3: 2$ & 2.23 & 142 & 0 \\
\hline MS $_{1}$ & 0.71 & $1: 3: 2$ & 1.97 & 140 & 1.4 \\
\hline SS $_{2}$ & 0.71 & $1: 3: 2$ & 1.63 & 137 & 3.5 \\
\hline $\mathrm{MS}_{3}$ & 0.71 & $1: 3: 2$ & 1.3 & 135 & 4.9 \\
\hline $\mathrm{MS}_{4}$ & 0.71 & $1: 3: 2$ & 1 & 131 & 7.7 \\
\hline
\end{tabular}

\subsection{Hardened properties}

For the assessment of hardened state mechanical properties compressive strength, flexural strength, splitting tensile strength and their corresponding pre-crack energy absorption, post-crack energy 
absorption, total energy absorption and toughness index were carried out on both the control specimens as well as on glass fiber modified specimens.

\subsubsection{Compressive strength test}

To assess the influence of GF on the compressive strength of concrete, ASTM C39/C39M-15a [76] standard method was followed and cylindrical specimens of 12" height and 6" diameter were used. The molds were oiled, and concrete with different percentages of GF was poured in cylinders and stored for $24 \pm 8$ hours at room temperature. Before the immersion of the specimen in water, specimens were stored in an open environment for 30 minutes, and then the specimens were kept in a water bath at $25^{\circ} \mathrm{C}$ for 7 , 14 , and 28 days, then the specimens were tested by using the universal testing machine (UTM). In order to obtain the average result of strength, 3 specimens were tested at each curing age.

\subsubsection{Flexural strength test}

Flexural test was performed according to ASTM C78/C78M-15b [77] provision. Specimens of 4 " $\times 4$ " $\times 20$ " beam were prepared for each mix of concrete and for the casting of samples, the same procedure was followed as for compressive strength. The beam specimens were tested according to ASTM C 78 provision using a third point load by UTM. After the failure of specimens, interpretations of the concrete matrix were made. The specimen's tensile strength was determined according to the given formula.

Strength of flexural test $(\mathrm{psi})=\frac{\mathrm{PL}}{\mathrm{BD}^{2}}$

Where,

$\mathrm{P}=$ Applied load

$L=$ span length

$B=$ Width in inches

$D=$ failure point depth in inches

\subsubsection{Tensile strength test}

Split tensile tests were performed according to C496/C496M-11 [78] provisions. Specimens of $6 " \times 12$ " cylinder were prepared for each Mix of concrete and for the casting of samples, the same procedure was followed as for compressive strength. The specimens were kept in a water tank for curing of 7, 14, and 28 days. The specimen's tensile strength was determined according to the given formula.

Strength of split tensile test $(\mathrm{psi})=\frac{2 \mathrm{P}}{\pi \mathrm{LD}}$ 
Where,

P=applied load

$\mathrm{L}=$ length

$\mathrm{D}=$ diameter

\subsubsection{Energy absorption and toughness indices}

The pre-crack energy absorption, post-crack energy absorption, total energy absorption and toughness index for Compression, splitting tensile and flexural are calculated in accordance with the past studies as described in the Table 4. The pre-crack energy absorption of compressive, flexural and splitting tensile strength (CPE, FPE, SPE) was taken as the load applied up to the first crack development. Similarly, the compressive, flexural and splitting tensile cracked energy absorption (CCE, FCE, SCE) was taken as the load from the first crack up to the maximum load taken by the sample in compression, flexural and splitting tensile. The stresses from zero to maximum absorbed by the sample in compression, flexural and splitting tensile were taken as total energy absorption (CE: P-Maximum), FE (P-Maximum), SE (PMaximum) respectively. Whereas, the compression, flexural and splitting tensile toughness indices (CTI, $\mathrm{FTI}, \mathrm{STI}$ ) were taken as the ratio between the maximum energy absorbed during the Compression, flexural and splitting tensile tests to the energy absorbed before compression, flexural and splitting tensile precracking energy (i.e. CE (Maximum-P)/CPE), FE (Maximum-P)/FPE), SE (P-Maximum)SPE), under the load deflection curve, respectively $[57,77,79,80,81,82]$.

Table 4: The parameters examined in accordance with the testing standards and past studies

\begin{tabular}{|lll|}
\hline Tests performed & Reference & Examined parameters \\
\hline Compressive properties & {$[57,76,79]$} & Compressive strength, CPE, CCE, CE (P-maximum), CTI \\
\hline Flexure properties & {$[77,83,84]$} & Flexure strength, FPE, FCE, FE (P-maximum), FTI \\
\hline Split-tensile properties & {$[57,78,79,85]$} & Split-tensile strength, SPE, SCE, SE (P-maximum), STI \\
\hline
\end{tabular}

\section{Results And Discussion}

\subsection{Compressive strength, energy absorption and toughness indices}

The utilization of low percentage of fiber to binding material is important in order to make a workable concrete mix and to get a homogenous distribution of fibers content within the plain cement composites [86]. Table 5 shows that even though the modified sample found to be workable, the compressive strength of the GFRC is significantly dependent on the percentage fibers in concrete.

Table 5: Compressive strength, COV, CPE, CCE, CE (Maximum-P), CTI of CS and GFRC for 28 days strength 


\begin{tabular}{|llllll|}
\hline Parametric Values & \multicolumn{5}{l}{ Different concrete samples } \\
\cline { 2 - 7 } & $\mathrm{CS}$ & $\mathrm{MS}_{1}$ & $\mathrm{MS}_{2}$ & $\mathrm{MS}_{3}$ & $\mathrm{MS}_{4}$ \\
\hline Compressive strength (psi) & 2887 & 2764 & 2747 & 2713 & 2650 \\
COV (\%) & 3.1 & 2.5 & 1.8 & 1.3 & 1.1 \\
\hline CPE (kN.s) & 1381.43 & 1305.63 & 1230.24 & 1195.50 & 1159.75 \\
CCE (kN.s) & 935.12 & 920.30 & 901.56 & 883.66 & 864.80 \\
CE (Maximum-P) (kN.s) & 2316.55 & 2225.93 & 2131.80 & 2079.16 & 2024.55 \\
CTI (-) & 1.68 & 1.70 & 1.73 & 1.74 & 1.75 \\
\hline
\end{tabular}

Figures 2 and 3 shows the change in behaviour of compressive strength of concrete with the increase in percentage of GF. It can be clearly observed that as the percentage of GF increases, the compressive strength of concrete decreases and the maximum drop in strength percentage occurred was $10.2 \%$ at the age of 14 days in $\mathrm{MS}_{4}$. This is Because of entanglement of some GF which might probably produce pores and cause a reduction in the compressive strength. Another reason could be the heterogeneity of $\mathrm{GF}$, besides, more binding material are required to coat the surface of the fiber when higher percentage of fibers are used and heterogeneity of GF with concrete. Similar trend and observation were made by the previous research studies on the compressive strength of fiber reinforced concrete $[57,86]$.

Compressive strength for 28 days is calculated from the maximum load of the Compressive test results [76]. The coefficient of variance, compressive strength, CPE, CCE, CE (Maximum-P) and CTI of CS and modified specimens are illustrated in Table 6 and Figure 4. The compressive strength of CS, $\mathrm{MS}_{1}, \mathrm{MS}_{2}$, $\mathrm{MS}_{3}$, and $\mathrm{MS}_{4}$ were 2887 psi, 2764 psi 2747 psi, 2713 psi, and 2650 psi, respectively. The compressive strength of $\mathrm{MS}_{1}, \mathrm{MS}_{2}, \mathrm{MS}_{3}$, and $\mathrm{MS}_{4}$ has decreased by $4.3 \%, 4.8 \%, 6.0 \%$ and $8.2 \%$, respectively, in comparison with the CS. The CPE of $\mathrm{CS}, \mathrm{MS}_{1}, \mathrm{MS}_{2}, \mathrm{MS}_{3}$, and $\mathrm{MS}_{4}$ were $1381.43 \mathrm{kN} . \mathrm{s}, 1305.63 \mathrm{kN} . \mathrm{s}$, 1230.24 kN.s, $1195.5 \mathrm{kN}$.s and $1159.75 \mathrm{kN} . \mathrm{s}$, respectively. The $\mathrm{CPE}$ of $\mathrm{MS}_{1}, \mathrm{MS}_{2}, \mathrm{MS}_{3}$, and $\mathrm{MS}_{4}$ reduced by $5.8 \%, 12.28 \%, 15.5 \%$, and $19.1 \%$, respectively in comparison with the CS. The CCE of CS, MS $1, M_{2}$, $\mathrm{MS}_{3}$, and $\mathrm{MS}_{4}$ were $935.12 \mathrm{kN} . \mathrm{s}, 920.30 \mathrm{kN} . \mathrm{s}, 901.56 \mathrm{kN} . \mathrm{s} 883.66 \mathrm{kN} . \mathrm{s}$ and $864.80 \mathrm{kN} . \mathrm{s}$, respectively. The CE (Maximum-P) of CS, $\mathrm{MS}_{1}, \mathrm{MS}_{2}, \mathrm{MS}_{3}$, and $\mathrm{MS}_{4}$ were $2316.55 \mathrm{kN} . \mathrm{s}, 2225.93 \mathrm{kN} . \mathrm{s}, 2131.80 \mathrm{kN} . \mathrm{s}$, $2079.16 \mathrm{kN}$.s and $2024.55 \mathrm{kN}$.s, respectively. The CE (Maximum-P) of CS, MS $1, \mathrm{MS}_{2}, \mathrm{MS}_{3}$, and $\mathrm{MS}_{4}$ were decreased by $3.92 \%, 7.98 \%, 10.25 \%$, and $12.61 \%$, respectively. The reason of the decrease in CPE, CCE and $C E$ (Maximum-P) in the modified samples could be the same as for compressive strength i.e. because of pores development, due to the entanglement, heterogeneity of GF, higher percentage of the fibers [57,86]. The CTI of CS, MS $, \mathrm{MS}_{2}, \mathrm{MS}_{3}$, and $\mathrm{MS}_{4}$ were 1.68, 1.70, 1.73, 1.74, and 1.74, respectively. Comparatively the CTI of $\mathrm{MS}_{1}, \mathrm{MS}_{2}, \mathrm{MS}_{3}$, and $\mathrm{MS}_{4}$ were increased by $1.19 \% 2.97 \%, 3.57 \%$ and $4.16 \%$ in comparison with the $\mathrm{CS}$, respectively. The $\mathrm{CTI}$ is increased due to the resistance provided by the glass fiber against the cracking phenomenon in concrete because GF provides significant resistance against 
stresses after development of cracks. Similar results and observation were made by the previous research studies on the fiber reinforced concrete compressive Strength, pre-crack energy absorption and toughness index $[57,86]$.

\subsection{Flexural strength, energy absorption and toughness indices}

The tests for Flexural strength were carried out at the age of 7, 14, and 28 days. Figures 5 and 6 show the change in behavior of the concrete with the increment in the percentage of GF. The results and data related to flexural strength revealed that, the flexural strength continuously increasing by increasing the percentage of fiber in the concrete mix. A maximum increase in the flexural strength of $21.5 \%$ was observed at the age of 28 days as compared to the control sample with the addition of $4 \%$ GF in the concrete mix. This is because of the efficiency of GF in controlling the cracks by delaying its first crack load $[87,88]$. Another reason could be the high elastic modulus and tensile strength of the GF which ultimately improves the flexural load carrying capacity of GFRC [89]. Similar trend and behavior of flexural strength was also reported by previous research studies by using glass fiber, steel fiber and carbon fiber etc. $[57,90,91]$.

Table 6: MOR, COV, FPE, FCE, FE (Maximum-P), FTI of CS and GFRC for 28 days strength

\begin{tabular}{|llllll|}
\hline Parametric Values & \multicolumn{5}{c|}{ Different concrete samples } \\
\cline { 2 - 6 } & $\mathrm{CS}$ & $\mathrm{MS}_{1}$ & $\mathrm{MS}_{2}$ & $\mathrm{MS}_{3}$ & $\mathrm{MS}_{4}$ \\
\hline MOR (psi) & 567 & 584 & 605 & 656 & 689 \\
COV (\%) & 1.2 & 2.3 & 1.6 & 1.4 & 1.3 \\
\hline FPE (kN.s) & 75.35 & 72.26 & 69.48 & 67.35 & 65.73 \\
\hline FCE (kN.s) & 0 & 5.66 & 9.96 & 13.22 & 15.05 \\
\hline FE (Maximum-P) (kN.s) & 75.35 & 77.92 & 79.44 & 80.57 & 80.78 \\
\hline FTI (-) & 1 & 1.07 & 1.14 & 1.19 & 1.22 \\
\hline
\end{tabular}

Modulus of rupture (MOR) for 28 days is calculated from the maximum load of the flexural load test [77]. The coefficient of variance, MOR, FPE, FCE, FE (Maximum-P) and FTI of CS, and modified samples are illustrated in Table 6 and Figure 7. The MOR of CS, MS $, M_{2}, M_{3}$, and $\mathrm{MS}_{4}$ were 567 psi, 584 psi 605 psi, 656 psi, and 689 psi respectively. The MOR of $\mathrm{MS}_{1}, \mathrm{MS}_{2}, \mathrm{MS}_{3}$, and $\mathrm{MS}_{4}$ has enhanced by $3.0 \%, 6.7 \%$, $15.7 \%$, and $21.5 \%$ respectively, in comparison with the CS.

The FPE of CS, $\mathrm{MS}_{1}, \mathrm{MS}_{2}, \mathrm{MS}_{3}$, and $\mathrm{MS}_{4}$ were $75.35 \mathrm{kN} . \mathrm{s}, 72.26 \mathrm{kN} . \mathrm{s}, 69.48 \mathrm{kN} . \mathrm{s}, 67.35 \mathrm{kN} . \mathrm{s}$ and 65.73 kN.s, respectively. The FPE of $\mathrm{MS}_{1}, \mathrm{MS}_{2}, \mathrm{MS}_{3}$, and $\mathrm{MS}_{4}$ were reduced by $4.2 \%, 8.4 \%, 11.8 \%$, and $14.63 \%$ 
respectively in comparison with the CS. The reason for the increased FPE of CS is that the first crack in CS appears at the maximum load and then it goes through brittle failure phenomena [57]. The FCE of CS, $\mathrm{MS}_{1}, \mathrm{MS}_{2}, \mathrm{MS}_{3}$, and $\mathrm{MS}_{4}$ were 0 kN.s, $5.66 \mathrm{kN} . \mathrm{s}, 9.96 \mathrm{kN} . \mathrm{s} 13.22 \mathrm{kN} . \mathrm{s}$ and $15.05 \mathrm{kN} . \mathrm{s}$, respectively. The FE (Maximum-P) of CS, $\mathrm{MS}_{1}, \mathrm{MS}_{2}, \mathrm{MS}_{3}$, and $\mathrm{MS}_{4}$ were 75.35 kN.s, $77.92 \mathrm{kN} . s, 79.44$ kN.s, $80.57 \mathrm{kN} . s$ and $80.78 \mathrm{kN}$.s, respectively. An incremental trend has been observed while increasing the percentage of glass fiber in the concrete which was $3.41 \%, 5.42 \%, 6.92 \%$, and 7.2\%. The FTI of CS, $\mathrm{MS}_{1}, \mathrm{MS}_{2}, \mathrm{MS}_{3}$, and $\mathrm{MS}_{4}$ were $1,1.07,1.14,1.19$, and 1.22 respectively. Comparatively, the $\mathrm{FTI}$ of $\mathrm{MS}_{1}, \mathrm{MS}_{2}, \mathrm{MS}_{3}$, and $\mathrm{MS}_{4}$ were increased by $7 \% 14 \%, 19 \%$, and $22 \%$ respectively, in comparison with the $\mathrm{CS}$. The increase in the FCE, FE (Maximum-P) and FTI could be the same as in flexural strength i.e. efficiency of GF of controlling the cracks, by delaying its first crack development $[87,88]$. Another reason could be the high elastic modulus and tensile strength of the GF, which ultimately provide the bridging effect and improves the FCE, FE (Maximum-P) and FTI of the modified specimens [89]. Similar incremental trend and behavior of flexural strength, toughness indices and energy absorption were reported by previous research studies by using glass fiber, steel fiber and carbon fiber etc. [57,90,91].

\subsection{Split tensile strength, energy absorption and toughness indices}

The tests for splitting tensile strength were carried out at the age of 7, 14, and 28 days. Figures 8 and 9 show the change in behavior of the concrete with the increment in the percentage of GF. The test results and data related to splitting tensile strength revealed that, the splitting tensile strength continuously increasing by increasing the percentage of fiber in the concrete mix. A maximum increase in splitting tensile strength of $31.2 \%$ was observed at the age of 28 days as compared to the control sample with the addition of $4 \%$ of GF in the concrete mix. This is because of the utilization of the maximum tensile strength capacity and bridging effect of GF under the splitting tensile load $[57,90]$. Similar trend and behavior of splitting tensile strength was also reported by previous research studies by using glass fiber, steel fiber and carbon fiber etc. [90,91,92].

Table 7: STS, COV, SPE, SCE, SE (Maximum-P), STI of CS and GFRC for 28 days strength

\begin{tabular}{|llllll|}
\hline Parametric Values & \multicolumn{5}{l}{ Different concrete samples } \\
\cline { 2 - 6 } & CS & MS1 & MS2 & MS3 & MS4 \\
\hline STS (psi) & 391 & 432 & 456 & 487 & 513 \\
COV (\%) & 1.4 & 1.7 & 1.9 & 1.8 & 1.1 \\
\hline SPE (kN.s) & 662.38 & 647.82 & 635.65 & 619.30 & 609.8 \\
\hline SCE (kN.s) & 0 & 80.44 & 115.35 & 140.50 & 164.95 \\
\hline SE (Maximum-P) (kN.s) & 662.38 & 728.26 & 751.00 & 759.8 & 774.75 \\
\hline STI (-) & 1 & 1.12 & 1.18 & 1.22 & 1.27 \\
\hline
\end{tabular}


The splitting tensile strength (STS) for 28 days was calculated from the maximum load taken by the specimen during the splitting tensile strength test [78]. The coefficient of variance, STS, SPE, SCE, SE (Maximum-P) and STI of CS, and modified are illustrated in Table 7 and Figure 10. The STS of CS, MS 1 , $\mathrm{MS}_{2}, \mathrm{MS}_{3}$, and $\mathrm{MS}_{4}$ were $391 \mathrm{psi}, 432$ psi, 456 psi, 487 psi and 513 psi respectively. The STS of $\mathrm{MS}_{1}$, $\mathrm{MS}_{2}, \mathrm{MS}_{3}$, and $\mathrm{MS}_{4}$ were increased by $41 \mathrm{psi}, 65 \mathrm{psi}, 96 \mathrm{psi}$ and $122 \mathrm{psi}$, respectively in comparison with the CS. The maximum value of STS was obtained for $\mathrm{MS}_{4}$ which was $513 \mathrm{psi}$. The SPE of CS, MS, $\mathrm{MS}_{2}$, $\mathrm{MS}_{3}$, and $\mathrm{MS}_{4}$ were $662.38 \mathrm{kN} . \mathrm{s}, 647.82 \mathrm{kN} . \mathrm{s}, 635.65 \mathrm{kN} . \mathrm{s}, 619.30 \mathrm{kN} . \mathrm{s}$ and $609.8 \mathrm{kN} . \mathrm{s}$, respectively. The SPE of $\mathrm{MS}_{1}, \mathrm{MS}_{2}, \mathrm{MS}_{3}$, and $\mathrm{MS}_{4}$ were reduced by $2.2 \%, 4.2 \%, 6.9 \%$, and $8.6 \%$ respectively in comparison with the CS.

The reason for the increased in SPE of CS is that the first crack in CS appears at the maximum load and then it goes through brittle failure phenomena [57]. The SCE of CS, MS $1, \mathrm{MS}_{2}, \mathrm{MS}_{3}$, and $\mathrm{MS}_{4}$ were $0 \mathrm{kN}$.s, 80.44 kN.s, 115.35 kN.s, 140.50 and 164.95 kN.s, respectively. The SE (Maximum-P) of CS, MS ${ }_{1}, M_{2}$, $\mathrm{MS}_{3}$, and $\mathrm{MS}_{4}$ were $662.38 \mathrm{kN} . \mathrm{s}, 728.26 \mathrm{kN} . \mathrm{s}, 751.00 \mathrm{kN} . \mathrm{s}, 759.8 \mathrm{kN} . \mathrm{s}$ and $774.75 \mathrm{kN} . \mathrm{s}$, respectively. An incremental trend has been observed while increasing the percentage of glass fiber in the concrete which was $9.9 \%, 13.37 \%, 16.21 \%$ and $16.9 \%$. The STI of CS, $\mathrm{MS}_{1}, \mathrm{MS}_{2}, \mathrm{MS}_{3}$, and $\mathrm{MS}_{4}$ were 1, 1.12, 1.18, 1.22, and 1.27 respectively. Comparatively the STI of $\mathrm{MS}_{1}, \mathrm{MS}_{2}, \mathrm{MS}_{3}$, and $\mathrm{MS}_{4}$ was increased by $12 \% 18 \%$, $22 \%$, and $27 \%$ in comparison with the CS, respectively. The increase in the SCE, SE (Maximum-P) and STI could be the same as in splitting tensile strength i.e. utilization of maximum tensile capacity of GF, and bridging effect of GF $[57,88,89]$. Similar fashion of increasing trend and behavior of splitting tensile strength, toughness indices and energy absorption were reported by previous research studies by using glass fiber, steel fiber and carbon fiber etc. [57,90,93].

\subsection{Discussion on optimization of glass fiber in concrete bridge decks}

The optimization of glass fiber content for control sample and modified sample are shown in Table 5-7. A study [94] was conducted on the mechanical and durability properties of glass and polypropylene fiber reinforced concrete and according to the authors, owing to the positive effect of bonding force between fibers and cement paste, the compressive and flexural strength of fiber reinforced concrete showed an obviously higher value than the control specimen. Another effective research [95] was carried out in which the authors reported that the maximum compressive strength was obtained at $1.2 \%$ percentage of fiber and achieved $13.14 \%$ increase over the control mix without using fibers. On the other hand, another study [57] was carried out in which the authors reported in their study that the compressive strength of GFRC will decrease with the addition of glass fibers. A similar result was reported in another study [96], that reduction in compressive strength will occur with the addition of fibers in concrete. A comparison of the past studies and current study are tabulated in Table 8.

Table 8: Comparison of modification with past research studies 


\begin{tabular}{|c|c|c|}
\hline Parameters & Compressive strength & $\begin{array}{l}\text { Flexural, Splitting tensile, toughness indices, } \\
\text { total energy absorption }\end{array}$ \\
\hline $\begin{array}{l}\text { Liu, J., Jia, Y., \& Wang, J. } \\
\text { (2019). }\end{array}$ & Increase at $1.5 \%$ GF & Increases \\
\hline $\begin{array}{l}\text { Mazen Hilles, M., \& Ziara, } \\
\text { M. M. (2018) }\end{array}$ & Increase at $1.2 \%$ GF & Increases \\
\hline $\begin{array}{l}\text { Khan, M., \& Ali, M. } \\
\text { (2016). }\end{array}$ & Decrease at $5 \%$ GF & Increases \\
\hline Current study & $\begin{array}{l}\text { Decreases at } 1 \%, 2 \% \text {, } \\
3 \% \text {, and } 4 \% \mathrm{GF}\end{array}$ & Increases at all levels of percentages \\
\hline
\end{tabular}

In the current research study, the effect of glass fibers of various percentages (i.e. $1 \%, 2 \%, 3 \%, 4 \%$ ) on the mechanical and durability properties of concrete were studied with w/c ratio of 0.71 and it was concluded that with the addition of glass fiber, the compressive strength was decreased which is exactly the coincident with past studies [57]. While the flexural, splitting tensile strength, pre-crack energy absorption, post-crack energy absorption, total energy absorption and toughness index were significantly increased. The similar results of improving the flexural, splitting tensile strength, pre-crack energy absorption, postcrack energy absorption, total energy absorption and toughness index were reported by the previous researchers in their studies. Based on the current study, it is concluded that the optimized glass fiber content for the modification of concrete is $4 \%$ by weight of cement, which can be used for the improvement of flexural strength, splitting tensile strength, toughness indices and total energy absorption. Moreover, the GFRC with optimized percentage of glass fiber can be used for the controlling of early age micro cracks in bridge deck and for durable concrete against aggressive environment as reported by the previous research studies $[37,57,72,73]$.

\section{Conclusion}

The following conclusions are drawn from this study:

i. The slump of GFRC specimens is reduced by increasing the dosages of glass fibers in comparison with the controlled specimens. For instance, it is reduced up to percentage level of $11.6 \%, 26.9 \%$, $41.7 \%$ and $55.1 \%$ for $\mathrm{MS}_{1}, \mathrm{MS}_{2}, \mathrm{MS}_{3}$, and $\mathrm{MS}_{4}$ respectively. Similarly, the density of GFRC was reduced by $1.4 \%, 3.5 \%, 4.9 \%$ and $7.7 \%$ for $\mathrm{MS}_{1}, \mathrm{MS}_{2}, \mathrm{MS}_{3}$, and $\mathrm{MS}_{4}$ respectively.

ii. The flexural and split-tensile strength of $\mathrm{MS}_{1}, \mathrm{MS}_{2}, \mathrm{MS}_{3}$, and $\mathrm{MS}_{4}$ is increased by increasing the dosages of glass fibers in the concrete as compared to the conventional concrete. The highest 
increment in the flexural and split tensile strength was $21.5 \%$ and $31.2 \%$ respectively, at $4 \%$ glass fiber content. Whereas, the compressive strength of $\mathrm{MS}_{1}, \mathrm{MS}_{2}, \mathrm{MS}_{3}$, and $\mathrm{MS}_{4}$ are reduced by increasing the content of glass fibers. The highest reduction of $8.2 \%$ for 28 days strength was observed when $4 \%$ of glass fiber was incorporated in concrete as compared with the conventional concrete.

iii. Flexural energy absorption is increased by $3.41 \%, 5.42 \%, 6.92 \%$ and $7.2 \%$, for $\mathrm{MS}_{1}, \mathrm{MS}_{2}, \mathrm{MS}_{3}$, and $\mathrm{MS}_{4}$ respectively as compared to that of the conventional concrete. Similarly, the splitting tensile energy absorption is increased by $9.9 \%, 13.37 \%, 16.21 \%$ and $16.9 \%$ for $\mathrm{MS} 1, \mathrm{MS}_{1}, \mathrm{MS}_{2}, \mathrm{MS}_{3}$, and $\mathrm{MS}_{4}$ On the other hand, the compressive energy absorption is decreased by $3.92 \%, 7.98 \%, 10.25 \%$ and $12.61 \%$ for $\mathrm{MS}_{1}, \mathrm{MS}_{2}, \mathrm{MS}_{3}$, and $\mathrm{MS}_{4}$ respectively as compared to conventional concrete.

iv. For $\mathrm{MS}_{1}, \mathrm{MS}_{2}, \mathrm{MS}_{3}$, and $\mathrm{MS}_{4}$, the toughness Indices of the compressive strength was increased by $1.19 \%, 2.97 \%, 3.57 \%$ and $4.16 \%$, it was increased by $7 \%, 14 \%, 19 \%$ and $22 \%$ for flexure while for split tensile it was increased by $12 \%, 18 \%, 22 \%$ and $27 \%$, as compared to that of the control specimen.

v. Among the different percentages of glass fibers, its $4 \%$ addition gives better results as compared to $1 \%, 2 \%$ and $3 \%$. Hence, the $4 \%$ of GF can be suggested to be the optimum percentage of the fibers for the selected mix-design in controlling the resistance of concrete in the bridge decks. However, the relevance of the findings by the authors encourages further study concerning the durability properties of concrete bridge decks incorporating glass fibers, besides; further study might be conducted for more mixture compositions of glass fibers (more than $4 \%$ ) in order to clearly summarize it before its applications.

\section{Declarations}

\section{Acknowledgments}

I wish to record my deep sense of gratitude and thanks to my Ph.D. supervisor Dr. Zhang Pu, professor, civil department, Zhengzhou university P.R. China. for his keen interest and guidance during the research work.

\section{Authors Contributions}

All authors whose names appear on the submission made substantial contributions to the conception, design of the work, acquisition, analysis, interpretation of data and writing/revision of the article

\section{Availability of data and material}

The data used to support the findings of this study are included within the article.

\section{Conflict of interest}

The authors declare that there is no conflict of interest. 


\section{Consent to participate}

Not applicable.

\section{Consent for publication}

Not applicable

\section{Funding}

This research received no specific grant from any funding agency.

\section{References}

1. Yin, S., Tuladhar, R., Shi, F., Combe, M., Collister, T., \& Sivakugan, N. (2015). Use of macro plastic fibres in concrete: A review. Construction and Building Materials, 93, 180-188. doi:10.1016/j.conbuildmat.2015.05.105

2. Kizilkanat, A. B., Kabay, N., Akyüncü, V., Chowdhury, S., \& Akça, A. H. (2015). Mechanical properties and fracture behavior of basalt and glass fiber reinforced concrete: An experimental study. Construction and Building Materials, 100, 218-224. doi:10.1016/j.conbuildmat.2015.10.006

3. Pakravan, H. R., \& Ozbakkaloglu, T. (2019). Synthetic fibers for cementitious composites: A critical and in-depth review of recent advances. Construction and Building Materials, 207, 491-518. doi:10.1016/j.conbuildmat.2019.02.078

4. Tassew, S. T., \& Lubell, A. S. (2014). Mechanical properties of glass fiber reinforced ceramic concrete. Construction and Building Materials, 51, 215-224. doi:10.1016/j.conbuildmat.2013.10.046

5. Shaikh, F. U. A. (2013). Review of mechanical properties of short fibre reinforced geopolymer composites. Construction and Building Materials, 43, 37-49.

doi:10.1016/j.conbuildmat.2013.01.026

6. Mehta, P.K., \& Monteiro, P.J.M. (2014). Concrete: Microstructure, Properties and Materials, fourth ed., McGraw-Hill Professional.

7. Sadrmomtazi, A., Tahmouresi, B., \& Saradar, A. (2018). Effects of silica fume on mechanical strength and microstructure of basalt fiber reinforced cementitious composites (BFRCC). Construction and Building Materials, 162, 321-333. doi:10.1016/j.conbuildmat.2017.11.159

8. Enfedaque, A., Cendón, D., Gálvez, F., \& Sánchez-Gálvez, V. (2010). Analysis of glass fiber reinforced cement (GRC) fracture surfaces. Construction and Building Materials, 24(7), 1302-1308. doi:10.1016/j.conbuildmat.2009.12.005

9. Koohestani, B., Darban, A. K., Mokhtari, P., Yilmaz, E., \& Darezereshki, E. (2018). Comparison of different natural fiber treatments: a literature review. International Journal of Environmental Science and Technology, 16(1), 629-642. doi:10.1007/s13762-018-1890-9 
10. Wu, T., Yang, X., Wei, H., \& Liu, X. (2019). Mechanical properties and microstructure of lightweight aggregate concrete with and without fibers. Construction and Building Materials, 199, 526-539. doi:10.1016/j.conbuildmat.2018.12.037

11. Chi, Y., Yu, M., Huang, L., \& Xu, L. (2017). Finite element modeling of steel-polypropylene hybrid fiber reinforced concrete using modified concrete damaged plasticity. Engineering Structures, 148, $23-35$. doi:10.1016/j.engstruct.2017.06.039

12. Yehia, S., Douba, A., Abdullahi, O., \& Farrag, S. (2016). Mechanical and durability evaluation of fiberreinforced self-compacting concrete. Construction and Building Materials, 121, 120-133. doi:10.1016/j.conbuildmat.2016.05.127

13. Li, B., Chi, Y., Xu, L., Shi, Y., \& Li, C. (2018). Experimental investigation on the flexural behavior of steelpolypropylene hybrid fiber reinforced concrete. Construction and Building Materials, 191, 80-94. doi:10.1016/j.conbuildmat.2018.09.202

14. Zhang, P., \& Li, Q. (2013). Effect of polypropylene fiber on durability of concrete composite containing fly ash and silica fume. Composites Part B: Engineering, 45(1), 1587-1594.

doi:10.1016/j.compositesb.2012.10.006

15. Fallah, S., \& Nematzadeh, M. (2017). Mechanical properties and durability of high-strength concrete containing macro-polymeric and polypropylene fibers with nano-silica and silica fume. Construction and Building Materials, 132, 170-187. doi:10.1016/j.conbuildmat.2016.11.100

16. Abaeian, R., Behbahani, H. P., \& Moslem, S. J. (2018). Effects of high temperatures on mechanical behavior of high strength concrete reinforced with high performance synthetic macro polypropylene (HPP) fibres. Construction and Building Materials, 165, 631-638.

doi:10.1016/j.conbuildmat.2018.01.064

17. Cao, S., Yilmaz, E., \& Song, W. (2019). Fiber type effect on strength, toughness and microstructure of early age cemented tailings backfill. Construction and Building Materials, 223, 44-54. https://doi.org/10.1016/j.conbuildmat.2019.06.221

18. Xu, L., Li, B., Ding, X., Chi, Y., Li, C., Huang, B., \& Shi, Y. (2018). Experimental Investigation on Damage Behavior of Polypropylene Fiber Reinforced Concrete under Compression. International Journal of Concrete Structures and Materials, 12(1), 1-20. https://doi.org/10.1186/s40069-018-0302-3

19. Xue, G., Yilmaz, E., Song, W., \& Cao, S. (2019). Mechanical, flexural and microstructural properties of cement-tailings matrix composites: Effects of fiber type and dosage. Composites Part B: Engineering, 172, 131-142. https://doi.org/10.1016/j.compositesb.2019.05.039

20. Xue, G., Yilmaz, E., Song, W., \& Yilmaz, E. (2019). Influence of fiber reinforcement on mechanical behavior and microstructural properties of cemented tailings backfill. Construction and Building Materials, 213, 275-285. doi:10.1016/j.conbuildmat.2019.04.080

21. Barluenga, G., \& Hernández-Olivares, F. (2007). Cracking control of concretes modified with short ARglass fibers at early age. Experimental results on standard concrete and SCC. Cement and Concrete Research, 37(12), 1624-1638. doi:10.1016/j.cemconres.2007.08.019 
22. Behfarnia, K., \& Behravan, A. (2014). Application of high performance polypropylene fibers in concrete lining of water tunnels. Materials \& Design, 55, 274-279.

doi:10.1016/j.matdes.2013.09.075

23. Beigi, M. H., Berenjian, J., Lotfi Omran, O., Sadeghi Nik, A., \& Nikbin, I. M. (2013). An experimental survey on combined effects of fibers and nanosilica on the mechanical, rheological, and durability properties of self-compacting concrete. Materials \& Design, 50, 1019-1029. doi:10.1016/j.matdes.2013.03.046

24. Li, J. jun, Niu, J. gang, Wan, C. jun, Jin, B., \& Yin, Y. liu. (2016). Investigation on mechanical properties and microstructure of high performance polypropylene fiber reinforced lightweight aggregate concrete. Construction and Building Materials, 118, 27-35. doi:10.1016/j.conbuildmat.2016.04.116

25. Mohseni, E., Khotbehsara, M. M., Naseri, F., Monazami, M., \& Sarker, P. (2016). Polypropylene fiber reinforced cement mortars containing rice husk ash and nano-alumina. Construction and Building Materials, 111, 429-439. doi:10.1016/j.conbuildmat.2016.02.124

26. Afroughsabet, V., \& Ozbakkaloglu, T. (2015). Mechanical and durability properties of high-strength concrete containing steel and polypropylene fibers. Construction and Building Materials, 94, 73-82. doi:10.1016/j.conbuildmat.2015.06.051

27. Hsie, M., Tu, C., \& Song, P. S. (2008). Mechanical properties of polypropylene hybrid fiber-reinforced concrete. Materials Science and Engineering: A, 494(1-2), 153-157. doi:10.1016/j.msea.2008.05.037

28. Ramezanianpour, A. A., Esmaeili, M., Ghahari, S. A., \& Najafi, M. H. (2013). Laboratory study on the effect of polypropylene fiber on durability, and physical and mechanical characteristic of concrete for application in sleepers. Construction and Building Materials, 44, 411-418. doi:10.1016/j.conbuildmat.2013.02.076

29. Simões, T., Costa, H., Dias-da-Costa, D., \& Júlio, E. (2017). Influence of fibres on the mechanical behaviour of fibre reinforced concrete matrixes. Construction and Building Materials, 137, 548-556. doi:10.1016/j.conbuildmat.2017.01.104

30. Sivakumar, A., \& Santhanam, M. (2007). Mechanical properties of high strength concrete reinforced with metallic and non-metallic fibres. Cement and Concrete Composites, 29(8), 603-608. doi:10.1016/j.cemconcomp.2007.03.006

31. Iucolano, F., Liguori, B., \& Colella, C. (2013). Fibre-reinforced lime-based mortars: A possible resource for ancient masonry restoration. Construction and Building Materials, 38, 785-789. doi:10.1016/j.conbuildmat.2012.09.050

32. Fang, Y., Chen, B., \& Oderji, S. Y. (2018). Experimental research on magnesium phosphate cement mortar reinforced by glass fiber. Construction and Building Materials, 188, 729-736. doi:10.1016/j.conbuildmat.2018.08.153

33. Pehlivanlı, Z. O., Uzun, I., \& Demir, İ. (2015). Mechanical and microstructural features of autoclaved aerated concrete reinforced with autoclaved polypropylene, carbon, basalt and glass fiber. Construction and Building Materials, 96, 428-433. doi:10.1016/j.conbuildmat.2015.08.104 
34. Choi, Y., \& Yuan, R. L. (2005). Experimental relationship between splitting tensile strength and compressive strength of GFRC and PFRC. Cement and Concrete Research, 35(8), 1587-1591. doi:10.1016/j.cemconres.2004.09.010

35. Çavdar, A. (2012). A study on the effects of high temperature on mechanical properties of fiber reinforced cementitious composites. Composites Part B: Engineering, 43(5), 2452-2463. doi:10.1016/j.compositesb.2011.10.005

36. Arslan, M. E. (2016). Effects of basalt and glass chopped fibers addition on fracture energy and mechanical properties of ordinary concrete: CMOD measurement. Construction and Building Materials, 114, 383-391. doi:10.1016/j.conbuildmat.2016.03.176

37. Liu, J., Jia, Y., \& Wang, J. (2019). Experimental Study on Mechanical and Durability Properties of Glass and Polypropylene Fiber Reinforced Concrete. Fibers and Polymers, 20(9), 1900-1908. doi:10.1007/s12221-019-1028-9

38. Güneyisi, E., Atewi, Y. R., \& Hasan, M. F. (2019). Fresh and rheological properties of glass fiber reinforced self-compacting concrete with nanosilica and fly ash blended. Construction and Building Materials, 211, 349-362. doi:10.1016/j.conbuildmat.2019.03.087

39. Yap, S. P., Bu, C. H., Alengaram, U. J., Mo, K. H., \& Jumaat, M. Z. (2014). Flexural toughness characteristics of steel-polypropylene hybrid fibre-reinforced oil palm shell concrete. Materials \& Design, 57, 652-659. doi:10.1016/j.matdes.2014.01.004

40. Cao, Q., Cheng, Y., Cao, M., \& Gao, Q. (2017). Workability, strength and shrinkage of fiber reinforced expansive self-consolidating concrete. Construction and Building Materials, 131, 178-185. doi:10.1016/j.conbuildmat.2016.11.076

41. Banthia, N., \& Gupta, R. (2006). Influence of polypropylene fiber geometry on plastic shrinkage cracking in concrete. Cement and Concrete Research, 36(7), 1263-1267. doi:10.1016/j.cemconres.2006.01.010

42. Pelisser, F., Neto, A. B. da S. S., Rovere, H. L. L., \& Pinto, R. C. de A. (2010). Effect of the addition of synthetic fibers to concrete thin slabs on plastic shrinkage cracking. Construction and Building Materials, 24(11), 2171-2176. doi:10.1016/j.conbuildmat.2010.04.041

43. Karahan, O., \& Atiş, C. D. (2011). The durability properties of polypropylene fiber reinforced fly ash concrete. Materials \& Design, 32(2), 1044-1049. doi:10.1016/j.matdes.2010.07.011

44. Ma, H., Yu, H., Li, C., Tan, Y., Cao, W., \& Da, B. (2018). Freeze-thaw damage to high-performance concrete with synthetic fibre and fly ash due to ethylene glycol deicer. Construction and Building Materials, 187, 197-204. doi:10.1016/j.conbuildmat.2018.07.189

45. Izaguirre, A., Lanas, J., \& Alvarez, J. I. (2011). Effect of a polypropylene fibre on the behaviour of aerial lime-based mortars. Construction and Building Materials, 25(2), 992-1000. doi:10.1016/j.conbuildmat.2010.06.080

46. Deo, S. V. (2015). Parametric Study of Glass Fiber Reinforced Concrete. Advances in Structural Engineering, 1909-1916. doi:10.1007/978-81-322-2187-6_147 
47. Bahar, A., Saffari, T.M., Afsoos, B.H., \& Kaafi, S.P. (2012). A Review of Advantages of Using Glass Fiber Reinforcement in Construction. International Congress on Durability of Concrete, vol. 2012, 11 pages.

48. Bakis, C. E., Bank, L. C., Brown, V., Cosenza, E., Davalos, J. F., Lesko, J. J., ... \& Triantafillou, T. C. (2002). Fiber-reinforced polymer composites for construction-State-of-the-art review. Journal of composites for construction, 6(2), 73-87.

49. Mazzoli, A., Monosi, S., \& Plescia, E. S. (2015). Evaluation of the early-age-shrinkage of Fiber Reinforced Concrete (FRC) using image analysis methods. Construction and Building Materials, 101, 596-601. doi:10.1016/j.conbuildmat.2015.10.090

50. Bijen, 1983). Durability of Some Glass Fiber Reinforced Cement Composites. (ACl Journal Proceedings, 80(4). doi:10.14359/10853

51. Leonard, S., \& Bentur, A. (1984). Improvement of the durability of glass fiber reinforced cement using blended cement matrix. Cement and Concrete Research, 14(5), 717-728. doi:10.1016/00088846(84)90035-8

52. Shah, S., Daniel, J. I., \& Ludirdja, D. (1987). Toughness of Glass Fiber Reinforced Concrete Panels Subjected to Accelerated Aging. PCl Journal, 32(5), 82-99. doi:10.15554/pcij.09011987.82.99

53. Zhang, Y., Sun, W., Shang, L., \& Pan, G. (1997). The effect of high content of fly ash on the properties of glass fiber reinforced cementitious composites. Cement and Concrete Research, 27(12), 18851891. doi:10.1016/s0008-8846(97)00203-2

54. Marikunte, S., Aldea, C., \& Shah, S. P. (1997). Durability of glass fiber reinforced cement composites: Advanced Cement Based Materials, 5(3-4), 100-108. doi:10.1016/s1065-7355(97)00003-5

55. Peled, A. (2005). Effect of matrix modification on durability of glass fiber reinforced cement composites. Materials and Structures, 38(276), 163-171. doi:10.1617/14091

56. Qureshi, L. A., \& Ahmed, A. (2013). An investigation on strength properties of glass fiber reinforced concrete. International Journal of Engineering Research and Technology, 2(4).

57. Khan, M., \& Ali, M. (2016). Use of glass and nylon fibers in concrete for controlling early age micro cracking in bridge decks. Construction and Building Materials, 125, 800-808. doi:10.1016/j.conbuildmat.2016.08.111

58. Yunovich, M., \& Thompson, N. G. (2003). Corrosion of highway bridges: Economic impact and control methodologies. Concrete International, 25(1), 52-57.

59. Humar, J. L., \& Razaqpur, A. G. (Eds.). (2000). Advanced composite materials in bridges and structures. Canadian Society for Civil Engineering.

60. Khanna, O. S., Mufti, A. A., \& Bakht, B. (2000). Experimental investigation of the role of reinforcement in the strength of concrete deck slabs. Canadian Journal of Civil Engineering, 27(3), 475-480. doi:10.1139/199-094

61. Steffen, R., Scott, D., Goodspeed, C., Bowman, M., \& Trunfio, J. (2003). Design issues and constructibility of a CFRP grid reinforced bridge deck. In High performance materials in bridges (pp. 106-116). doi:10.1061/40691(2003)10 
62. Bradberry, T. E., \& Wallace, S. (2003). FRP reinforced concrete in Texas transportation past, present, future. Special Publication, 215, 3-36.

63. Stone, D., Nanni, A., \& Myers, J. (2001, October). Field and laboratory performance of FRP bridge panels. In Proceedings of the International Conference on Composites in Construction (pp. 10-12).

64. Huckelbridge, A. A., \& Eitel, A. K. (2003). Preliminary performance observations for an FRP reinforced concrete bridge deck. Special Publication, 215, 121-138.

65. Federal Highway Administration FHwA. (2003). Completed FRP deck projects. http://www.fhwa.dot.gov/bridge/frp/deckproj.htm

66. Federal Highway Administration/New York FHwA/NY. (2000). Design, fabrication, construction, and testing of a FRP superstructure. Special Rep.134 (SR-134), Transportation Research and Development Bureau, New York State Department of Transportation, Albany, N.Y.

67. Ali, B., Qureshi, L. A., Raza, A., Nawaz, M. A., Rehman, S. U., \& Rashid, M. U. (2019). Influence of Glass Fibers on Mechanical Properties of Concrete with Recycled Coarse Aggregates. Civil Engineering Journal, 5(5), 1007-1019. doi:10.28991/cej-2019-03091307

68. Kizilkanat, A. B., Kabay, N., Akyüncü, V., Chowdhury, S., \& Akça, A. H. (2015). Mechanical properties and fracture behavior of basalt and glass fiber reinforced concrete: An experimental study. Construction and Building Materials, 100, 218-224. doi:10.1016/j.conbuildmat.2015.10.006

69. Liu, X., Yan, M., Galobardes, I., \& Sikora, K. (2018). Assessing the potential of functionally graded concrete using fibre reinforced and recycled aggregate concrete. Construction and Building Materials, 171, 793-801. doi:10.1016/j.conbuildmat.2018.03.202

70. Ferreira, J. P. J. G., \& Branco, F. A. B. (2007). THE USE OF GLASS FIBER?REINFORCED CONCRETE AS A STRUCTURAL MATERIAL. Experimental Techniques, 31(3), 64-73. doi:10.1111/j.17471567.2007.00153.x

71. Specifiers Guide to Glass Reinforced Concrete. Glass reinforced concrete association. Northampton: International Glass fibre Reinforced Cement Association; (2012), 1-4.

72. Chen, F. (2013). An Experimental study on mechanical properties of basalt fiber reinforced concrete. In Applied Mechanics and Materials (Vol. 405, pp. 2767-2770). Trans Tech Publications Ltd.

73. Hilles, M. M., \& Ziara, M. M. (2019). Mechanical behavior of high strength concrete reinforced with glass fiber. Engineering Science and Technology, an International Journal, 22(3), 920-928.

74. ASTM C143/C143M-15a, Standard Test Method for Slump of HydraulicCement Concrete, ASTM International, West Conshohocken, PA, 2015, http:// www.astm.org.

75. ASTM C138/C138M-16, Standard Test Method for Density (Unit Weight), Yield, and Air Content of Concrete, ASTM International, West Conshohocken, PA, 2016, http://www.astm.org.

76. ASTM C39/C39M-15a, Standard Test Method for Compressive Strength of Cylindrical Concrete Specimens, ASTM International, West Conshohocken, PA, 2015, http://www.astm.org.

77. ASTM C78/C78M-15b, Standard Test Method for Flexural Strength of Concrete (Using Simple Beam with Third-Point Loading), ASTM International, West Conshohocken, PA, 2016, http://www.astm.org. 
78. ASTM C496/C496M-11, Standard Test Method for Splitting Tensile Strength of Cylindrical Concrete Specimens, ASTM International, West Conshohocken, PA, 2004, http://www.astm.org.

79. Zia, A., \& Ali, M. (2017). Behavior of fiber reinforced concrete for controlling the rate of cracking in canal-lining. Construction and Building Materials, 155, 726-739. doi:10.1016/j.conbuildmat.2017.08.078

80. Fanella, D. A., and Naaman, A. E. (1985).Stress-Strain Properties of Fiber Reinforced Mortar in Compression." ACl Journal Proceedings 82, no. 4 475-483 doi:10.14359/10359.

81. Shah, S., Daniel, J. I., \& Ludirdja, D. (1987). Toughness of Glass Fiber Reinforced Concrete Panels Subjected to Accelerated Aging. PCl Journal, 32(5), 82-99. doi:10.15554/pcij.09011987.82.99

82. Wedding, P., \& Johnston, C. (1982). Definition and Measurement of Flexural Toughness Parameters for Fiber Reinforced Concrete. Cement, Concrete and Aggregates, 4(2), 53. doi:10.1520/cca10228j

83. ASTM C1609 / C1609M-10, Standard Test Method for Flexural Performance of Fiber-Reinforced Concrete (Using Beam With Third-Point Loading), ASTM International, West Conshohocken, PA, 2010, www.astm.org

84. ASTM C1018-97, Standard Test Method for Flexural Toughness and First-Crack Strength of FiberReinforced Concrete (Using Beam With Third-Point Loading) (Withdrawn 2006), ASTM International, West Conshohocken, PA, 1997, astm.org

85. ASTM E1820-20b, Standard Test Method for Measurement of Fracture Toughness, ASTM International, West Conshohocken, PA, 2020, www.astm.org

86. Mebarkia, S., \& Vipulanandan, C. (1992). Compressive Behavior of Glass-Fiber Reinforced Polymer Concrete. Journal of Materials in Civil Engineering, 4(1), 91-105. doi:10.1061/(asce)08991561(1992)4:1(91)

87. Chan, R., Santana, M. A., Oda, A. M., Paniguel, R. C., Vieira, L. B., Figueiredo, A. D., \& Galobardes, I. (2019). Analysis of potential use of fibre reinforced recycled aggregate concrete for sustainable pavements. Journal of Cleaner Production, 218, 183-191.

https://doi.org/10.1016/j.jclepro.2019.01.221

88. Ahmadi, M., Farzin, S., Hassani, A., \& Motamedi, M. (2017). Mechanical properties of the concrete containing recycled fibers and aggregates. Construction and Building Materials, 144, 392-398. doi:10.1016/j.conbuildmat.2017.03.215

89. Raza, S. S., Qureshi, L. A., Ali, B., Raza, A., Khan, M. M., \& Salahuddin, H. (2020). Mechanical Properties of Hybrid Steel-Glass Fiber-Reinforced Reactive Powder Concrete After Exposure to Elevated Temperatures. Arabian Journal for Science and Engineering, 45(5), 4285-4300. doi:10.1007/s13369-020-04435-4

90. Ali, B., Qureshi, L. A., \& Khan, S. U. (2020). Flexural behavior of glass fiber-reinforced recycled aggregate concrete and its impact on the cost and carbon footprint of concrete pavement. Construction and Building Materials, 262, 120820. doi:10.1016/j.conbuildmat.2020.120820

91. Ali, B., Raza, S. S., Hussain, I., \& Iqbal, M. (2020). Influence of different fibers on mechanical and durability performance of concrete with silica fume. Structural Concrete. 
doi:10.1002/suco.201900422

92. Marikunte, S., Aldea, C., \& Shah, S. P. (1997). Durability of glass fiber reinforced cement composites: Advanced Cement Based Materials, 5(3-4), 100-108. doi:10.1016/s1065-7355(97)00003-5

93. Raza, S. S., Qureshi, L. A., Ali, B., Raza, A., \& Khan, M. M. (2020). Effect of different fibers (steel fibers, glass fibers, and carbon fibers) on mechanical properties of reactive powder concrete. Structural Concrete. doi:10.1002/suco.201900439

94. Liu, J., Jia, Y., \& Wang, J. (2019). Experimental Study on Mechanical and Durability Properties of Glass and Polypropylene Fiber Reinforced Concrete. Fibers and Polymers, 20(9), 1900-1908. doi:10.1007/s12221-019-1028-9

95. Mazen Hilles, M., \& Ziara, M. M. (2018). Mechanical Behavior of High Strength Concrete Reinforced with Glass Fiber Reinforced Polymer. Journal of Civil \& Environmental Engineering, 08(04). doi:10.4172/2165-784x.1000318

96. Khan, M., Rehman, A., \& Ali, M. (2020). Efficiency of silica-fume content in plain and natural fiber reinforced concrete for concrete road. Construction and Building Materials, 244, 118382. https://doi.org/10.1016/j.conbuildmat.2020.118382

\section{Figures}

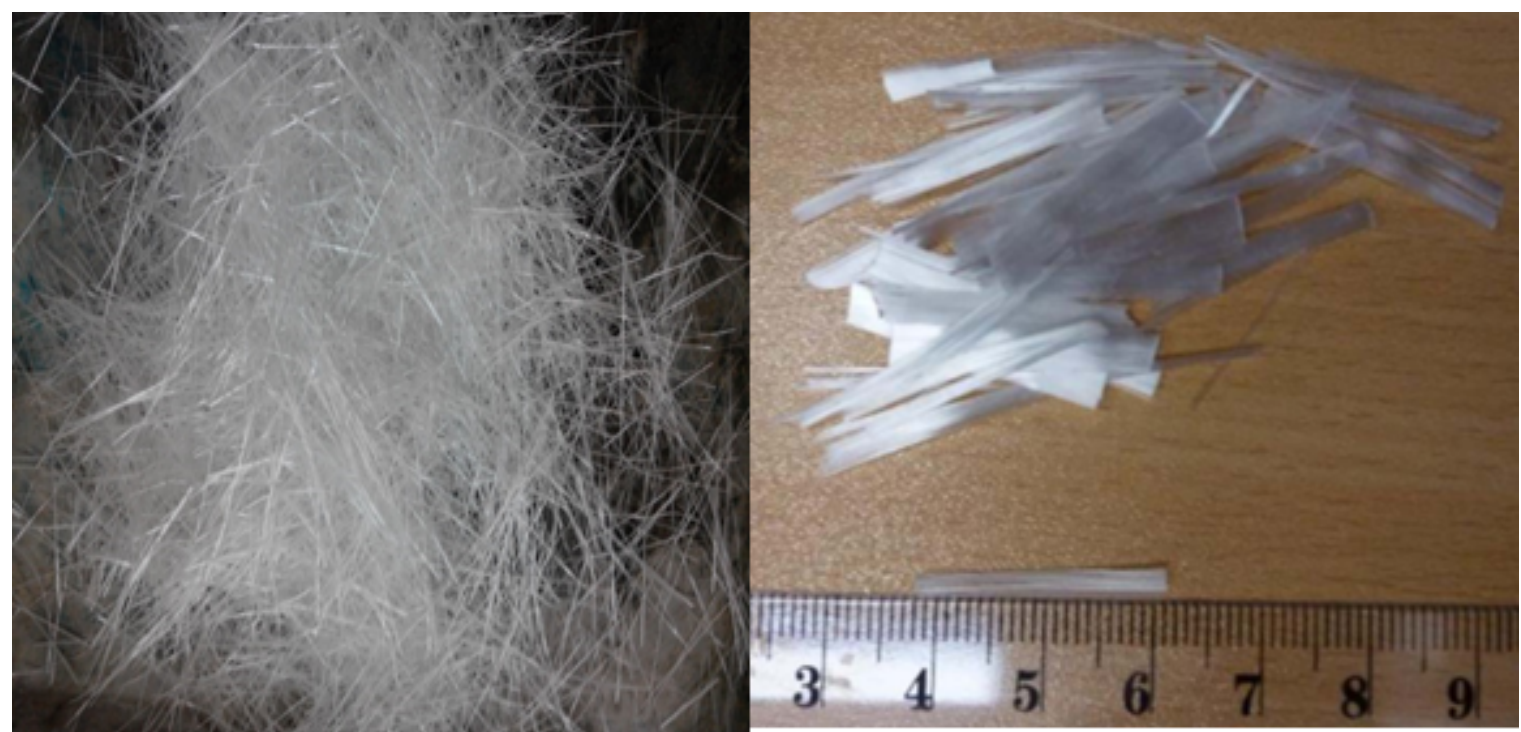

\section{Figure 1}

Image of the glass fibers used in this study 


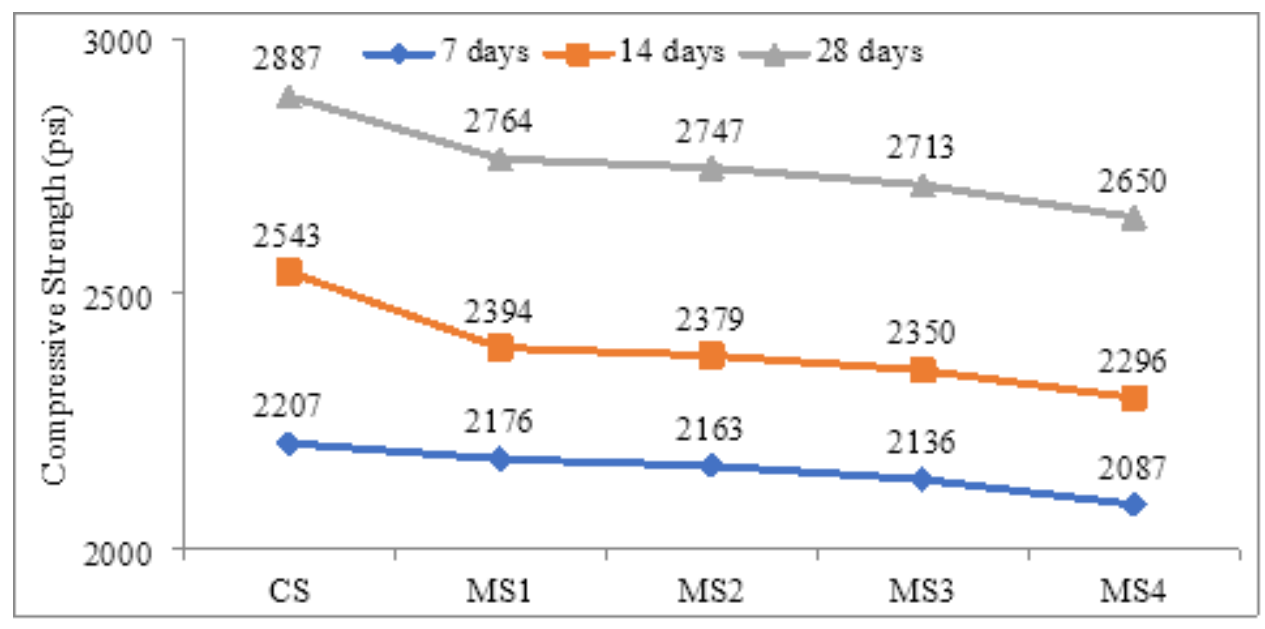

Figure 2

comparison of compressive strength at 7, 14 and 28 days

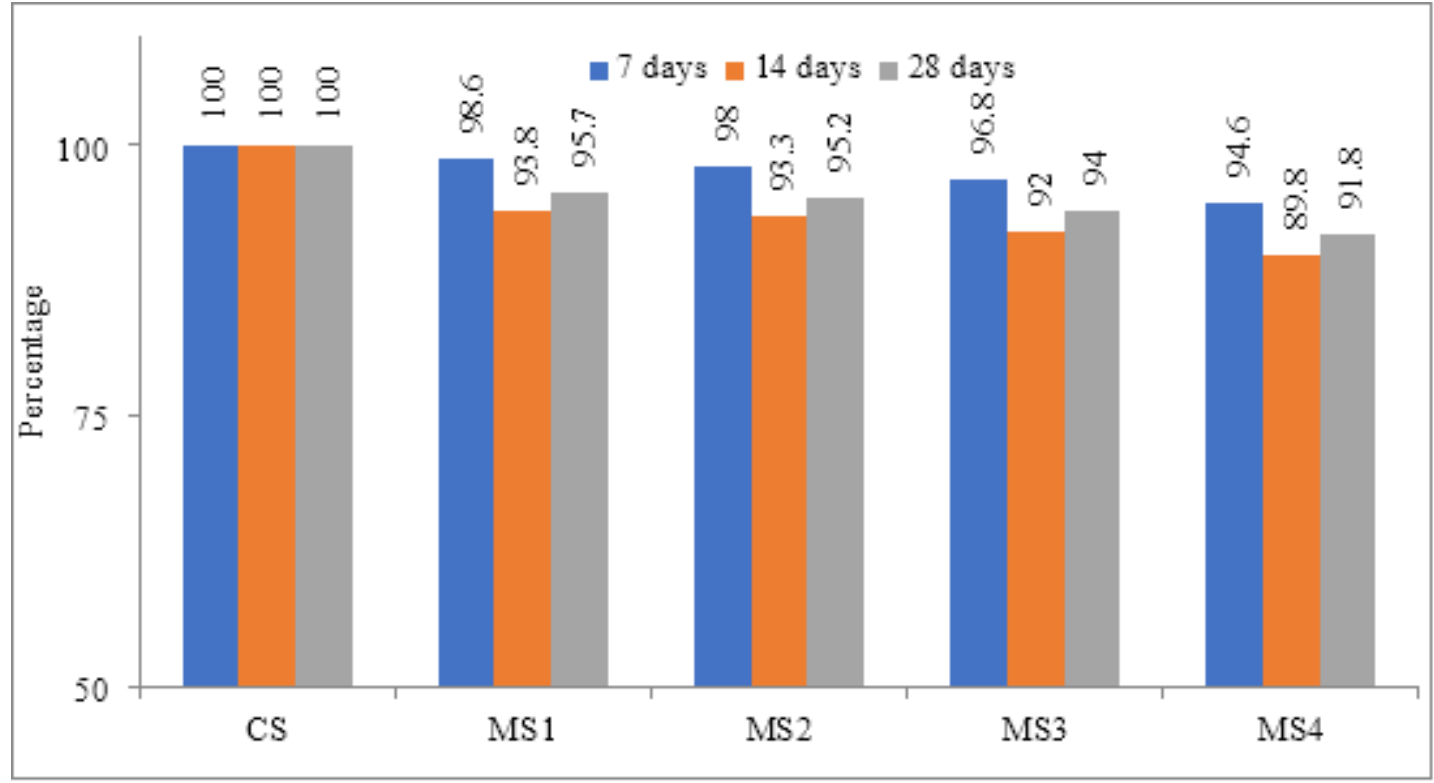

Figure 3

Drop in compressive strength (\%age) 


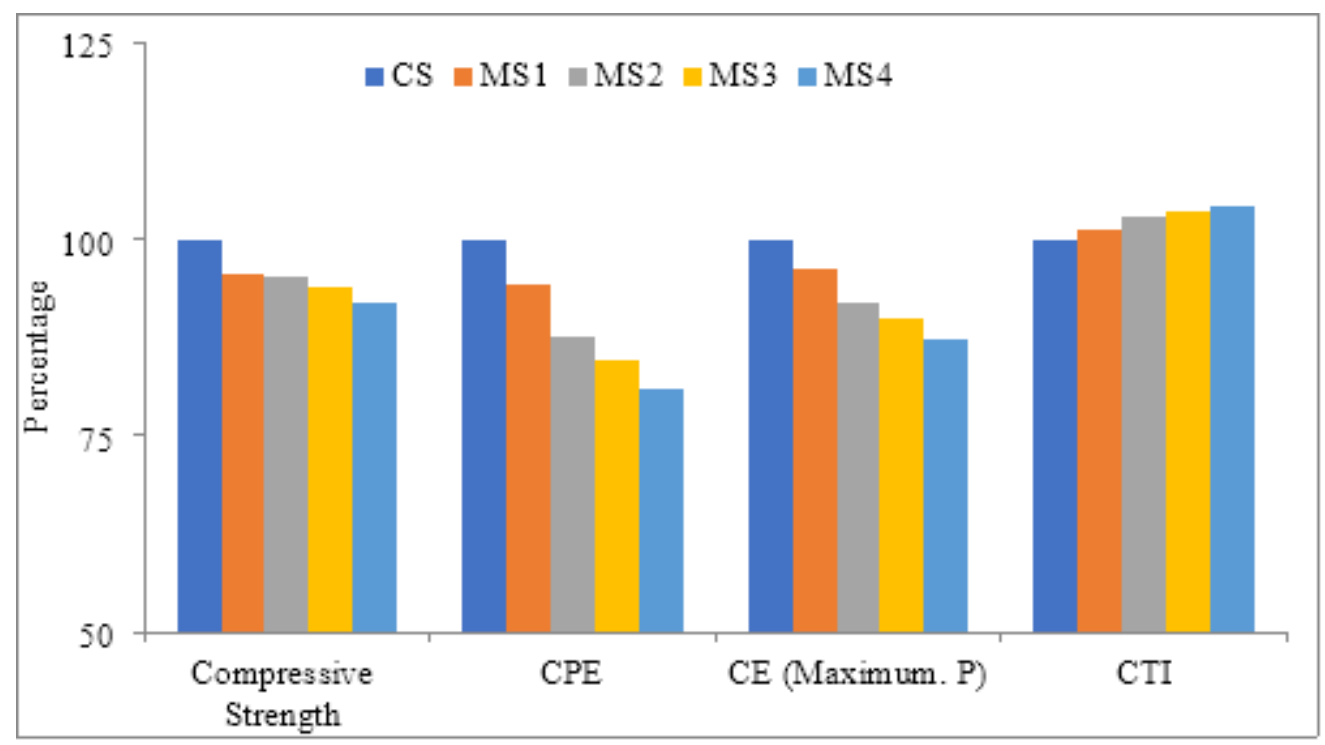

Figure 4

comparison of Compressive strength, CPE, CCE, CE (Maximum-P), CTI of CS and GFRC for 28 days strength.

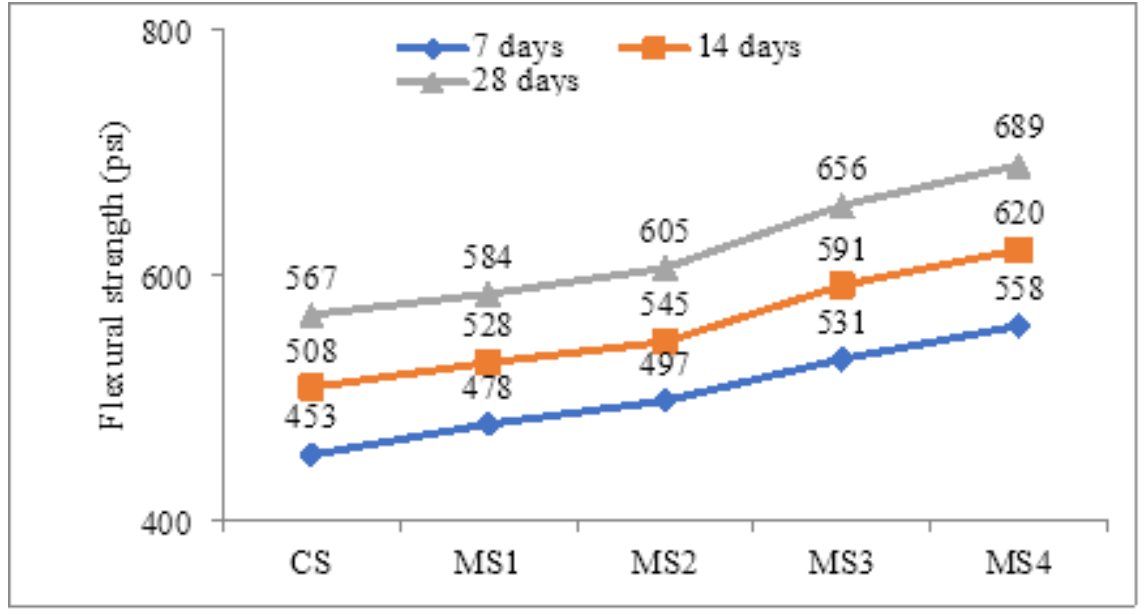

Figure 5

Comparison of Flexural strength at 7, 14, and 28 day 


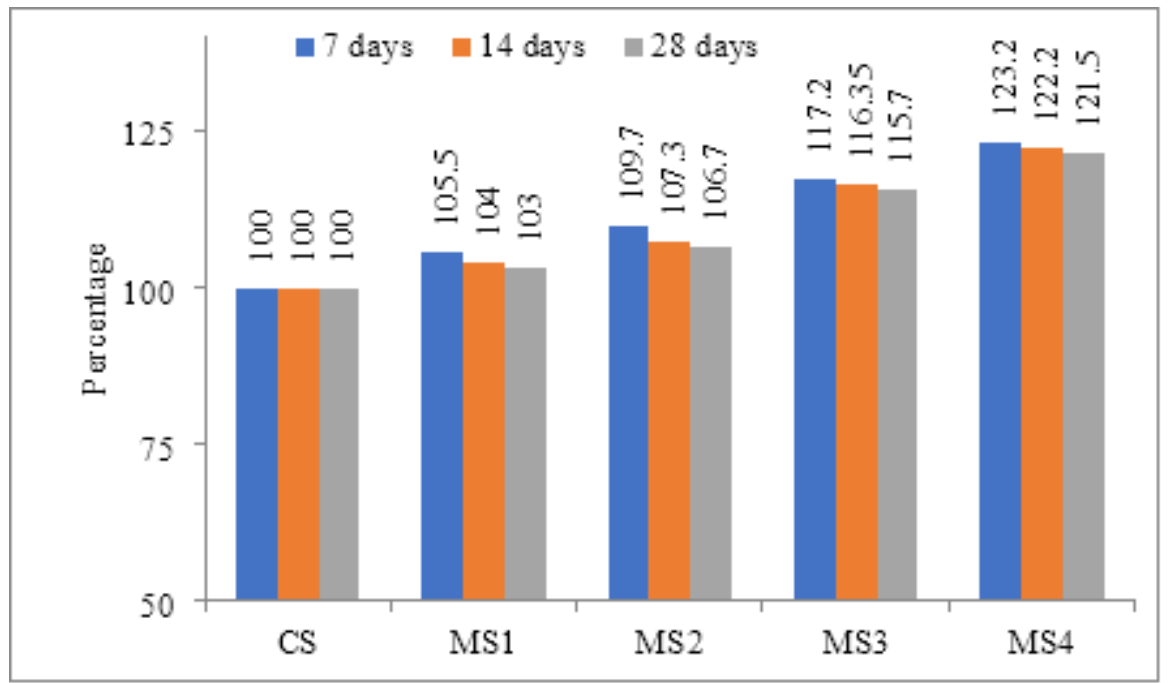

\section{Figure 6}

Increase in Flexural Strength (\%age)

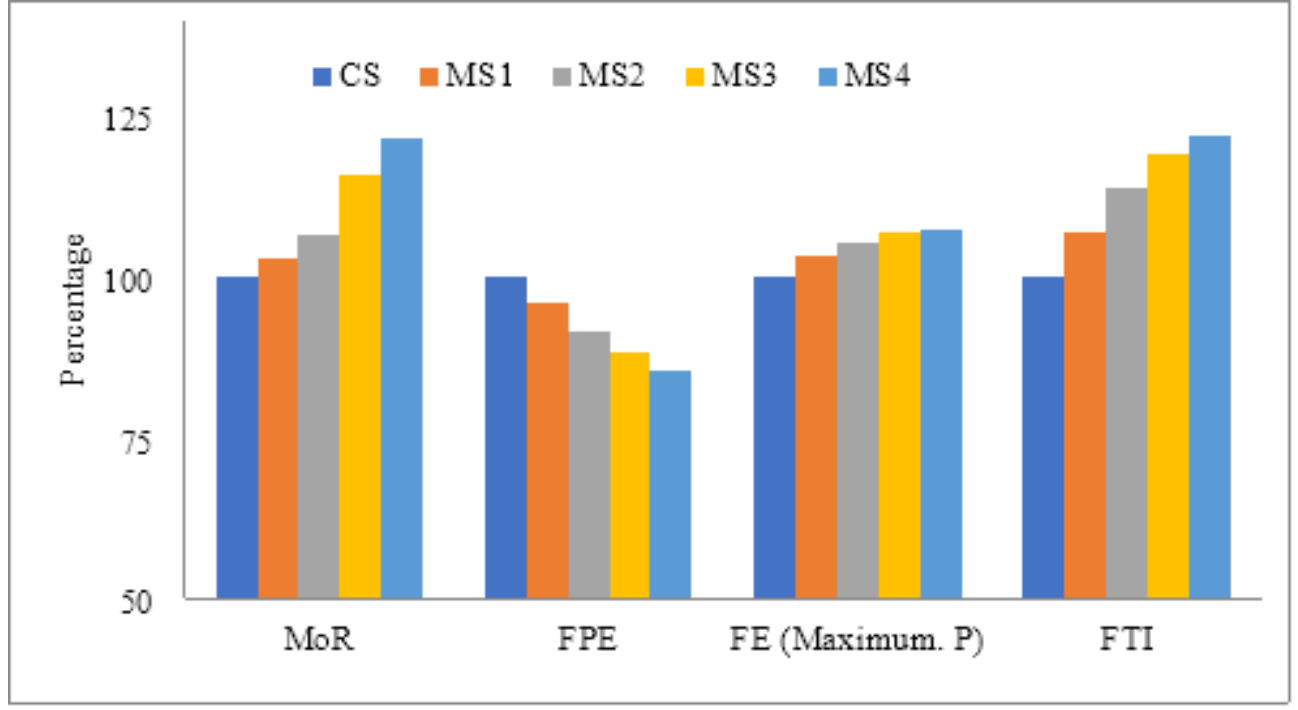

Figure 7

Comparison of MOR, FPE, FCE, FE (Maximum P), FTI of CS and GFRC for 28 days strength.

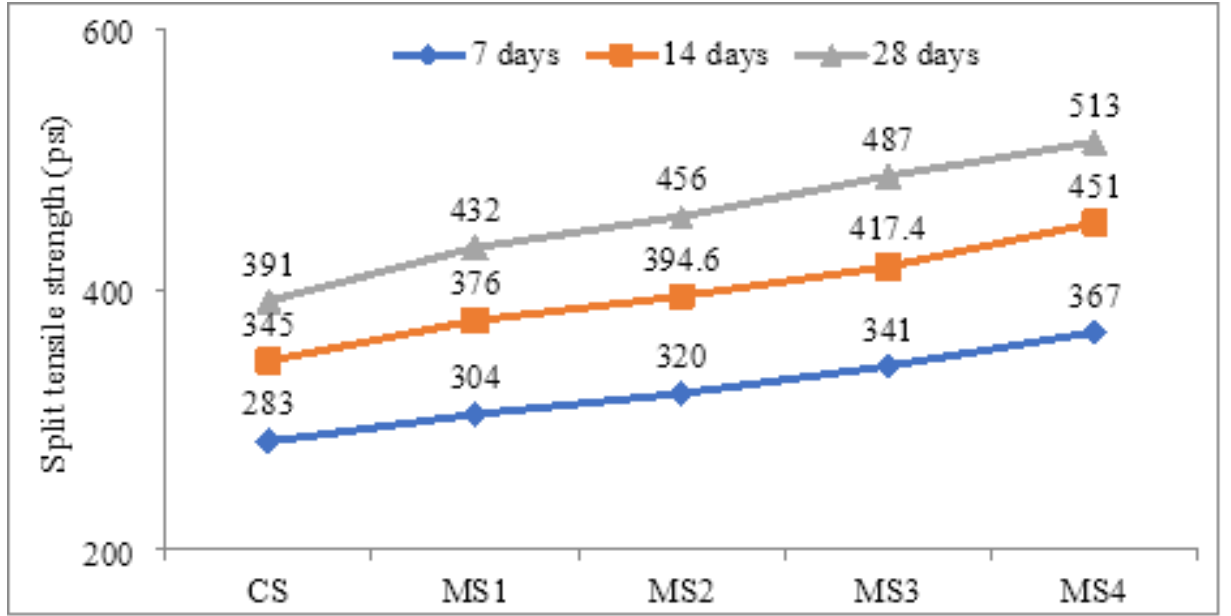


Figure 8

Comparison of split tensile strength at 7,14 , and 28 days

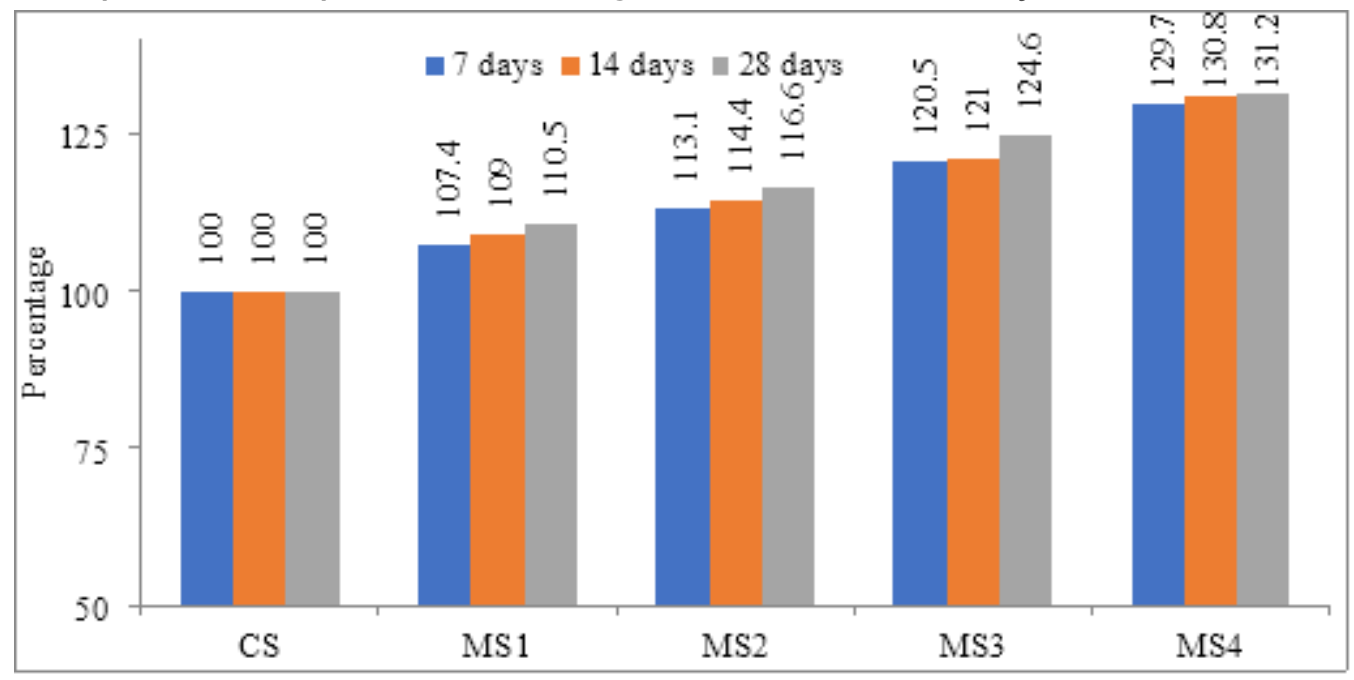

Figure 9

Increase in Split Tensile Strength (\%)



Figure 10

Comparison of STS, SPE, SCE, SE (Maximum P), STI of CS and GFRC for 28 days strength. 